FIGHTING THE GREAT WAR 


\section{FIGHTING THE GREAT WAR}

HARVARD UNIVERSITY PRESS

Cambridge, Massachusetts

London, England 2005 
A Global History

MICHAEL S. NEIBERG 
Copyright (C) 2005 by the President and Fellows of Harvard College

All rights reserved

Printed in the United States of America

Designed by Dean Bornstein

Pages ii-iii: Australian troops charge a Turkish

trench in the Dardanelles, ca. I9I5. (C) Corbis.

Library of Congress Cataloging-in-Publication Data

Neiberg, Michael S.

Fighting the Great War : a global history / Michael S. Neiberg.

p. $\mathrm{cm}$.

Includes bibliographical references and index.

ISBN o-674-0I696-3 (alk. paper)

I. World War, 19I4-I9I8-History. 2. History, Modern-2oth century. I. Title.

D52I.N44 2005

$940.4-\mathrm{dc22} \quad 2004054330$ 
For Dennis Showalter 
